The Moon-God Khons and the King's Placenta

Author(s): G. van der Leeuw

Source: The Journal of Egyptian Archaeology, Vol. 5, No. 1 (Jan., 1918), p. 64

Published by: Egypt Exploration Society

Stable URL: http://www.jstor.org/stable/3853552

Accessed: 22-06-2016 18:52 UTC

Your use of the JSTOR archive indicates your acceptance of the Terms \& Conditions of Use, available at

http://about.jstor.org/terms

JSTOR is a not-for-profit service that helps scholars, researchers, and students discover, use, and build upon a wide range of content in a trusted

digital archive. We use information technology and tools to increase productivity and facilitate new forms of scholarship. For more information about JSTOR, please contact support@jstor.org.

Egypt Exploration Society is collaborating with JSTOR to digitize, preserve and extend access to The Journal of Egyptian Archaeology 


\title{
THE MOON-GOD KHONS AND THE KING'S PLACENTA
}

\author{
By DR G. VAN DER LEEUW
}

IT is with the greatest interest that I have read the article by $\mathrm{Mr} \mathrm{A}$. M. Blackman on the Pharaoh's Placenta and the Moon-god Khons in a previous number of this periodical'. My interest has been yet further increased by the circumstance that Mr Blackman and I have, independently from one another, arrived at analogous results as to important questions. In particular as regards the $K a$ as at once a protecting spirit and a vital force (personality) there is a singular coincidence between Mr Blackman's views and my own, as expressed in an article that will appear shortly in the Zeitschrift für ägyptische Sprache.

There is one point which Mr Blackman confesses himself unable to elucidate completely, namely, how the Moon-god Khons (h-ni-św) should have come to his name "Placenta of the King"? In other words, what has the moon to do with a placenta?

With the Baganda, from whose conceptions Mr Blackman's argument takes its departure, the moon has also something to do with the afterbirth. But why?

In order to clear up this problem, we must revert to Mr Blackman's interesting explanation of the placenta as the twin or the double of the royal child. If this is true-and there seems to be little doubt about it-can the moon possibly have been considered as the twin of somebody?

The answer I would venture to suggest is this: the moon can only be considered as twin to the sun. There is no direct evidence for this, as far as I know, in Egyptian texts, but passages like Pyr. 128, where sun and moon are addressed together as the C8 If to suggest a close affinity between sun and moon as existing in Egyptian minds apart from the other conception of them as two eyes.

Given also that the sun, $\operatorname{Re}^{e}$, is the king par excellence, the suggestion that the moon, Khons, was considered at one time as the placenta of the king, namely the sun, may not be too bold, though not susceptible of exact proof.

1 Vol. III, pp. 235-249.

2 Cf. BREAșted, Religion and Thought, p. 137, and my book Godsvoorstellingen in de oud-Aegyptische Pyramidetexten, Leyden, 1916, p. 58, note 3. 